\title{
Profiling international migrant labours by socio-demographic characteristics and motivational factors: The case of tourism and hospitality industry
}

\author{
Nurhazani Mohd Shariff ${ }^{\text {, }}$, Nor Ashikin Mohd Nor ${ }^{1}$, Azlan Zainol Abidin ${ }^{2}$ \\ ${ }^{1}$ School of Tourism, Hospitality \& Environmental Management, UUM COLGIS, Universiti Utara Malaysia, 06010 Sintok, Kedah, \\ Malaysia \\ ${ }^{2}$ School of Languages, Civilization \& Philosophy, UUM CAS, Universiti Utara Malaysia, 06010, Sintok, Kedah, Malaysia
}

\section{A R T I C L E IN F O}

\section{Article history:}

Received 5 November 2016

Received in revised form

1 February 2017

Accepted 3 February 2017

\section{Keywords:}

International migrant labors

Socio-demographic characteristics

Motivational factors

Tourism and hospitality industry Profiling

\begin{abstract}
A B S T R A C T
Purpose of this study is to profile the international migrant labours who are legally working in the tourism and hospitality industry in Malaysia. Langkawi has been chosen to present the scope of the study due to the fact that it is a world tourist destination. The profile presents a various pattern of international migrant labours socio-demographic characteristics and factors motivating them to work in the industry. It is noted that majority of the international migrant labours who are working in the tourism and hospitality industry in Langkawi consists of male within the range of $18-30$ years old and single. Interestingly, majority of them are Indonesian, having a certificate and mostly educated from secondary school. Majority of them also contributes as semi-skilled labours. Regardless of various sectors in the tourism and hospitality industry, the international migrant labours enjoy working in the accommodation sector. Most of them have been working for 1 - 5 years and receiving an income of RM1,000 - RM4,999 per month. The profile also highlights that majority of the international migrant labours want to gain new experience and most of them are also following their friends. Langkawi is chosen as a destination due to the fact that it is a beautiful island, easy to get around and also a peaceful place to work. Further, it is emphasized in the profile that the international migrant labours have chosen to work in the accommodation sector based on high wages factor.
\end{abstract}

(c) 2017 The Authors. Published by IASE. This is an open access article under the CC BY-NC-ND license (http://creativecommons.org/licenses/by-nc-nd/4.0/).

\section{Introduction}

Malaysia has a growing international labour work force, with the vast majority employed as fulltime labours. By March 2004, there was 1.2 million international migrant workers in Malaysia with 77 149 working in the service sectors including tourism and hospitality. There is about 12.5 million international migrant workers in Malaysia with 11 million number of workforce available compared to the year 1995 where only $35 \%$ of workforce employed by migrant workers (Hassan, 2009). Further, 1.8 million international migrant workers in Malaysia with the highest percentage was from Indonesia (50.9\%), followed by Bangladesh (17\%), Nepal (9.7\%), Myanmar (7.8\%), India (6.3\%) and

\footnotetext{
* Corresponding Author.

Email Address: hazani@uum.edu.my (N. M. Shariff) https://doi.org/10.21833/ijaas.2017.02.011

2313-626X/C 2017 The Authors. Published by IASE.

This is an open access article under the CC BY-NC-ND license

(http://creativecommons.org/licenses/by-nc-nd/4.0/)
}

Vietnam (4.2\%) were listed in the Economic Report $2010 / 2011$

It is noted in the World Bank report (Del Carpio et al., 2013) that the presence of international labours has been a key factor in Malaysia's competitiveness and economic success. Hence, to meet the demands for low-skilled labour in certain sectors of the economy, the Government has supported immigration as part of its high growth strategy while it pursued a longer-term strategy to upgrade the economy and expand the supply of skilled labor particularly in plantations, constructions sector and domestic employment.

According to the Human Resources Minister Datuk Seri Richard Riot, there is an estimated 6.7 million international labours who are working in various sectors in Malaysia with 2.1 million are legal and 4.6 million are unauthorized workers. Generally, there are 2.135 million registered international labours in Malaysia with almost 800,000 legal international labours who are working in unskilled sectors ranging from cleaners, helpers, labourers, service workers and garbage collectors. Further, 
there are also nearly 300,000 international labours who are working in services and sales and machine operators and around 213,000 are employed in the manufacturing industry and related industries.

As stated by the International Organization for Migration (IOM, 2010), Malaysia, Singapore and destination countries in the Middle East desire and require labour forces that are low skilled or willing to embark on low-skilled jobs that their citizens are unwilling to take at the usual wages. The higher demand for these labours in many destination countries has been the main factor that contributes to the rise of irregular migration, with the estimated number of undocumented migrant workers considerably higher than the number of documented migrants.

Ajis et al. (2014) highlighted that the countries in Asia can be considered as the major providers of foreign immigrants, especially in the perspective of employment in this world. The entry of international labours is more than often related with three assumptions, which are economic liberation, noneffective law on border enforcement non-uniformity in economic opportunity. Hence, migrant labours are expected to be a part of social process which is more than often associated with issues like economic market, the change of policies in importing countries and transnational offering of labour as well as the rights of migrant labours.

It is a fact that the international migrant labours have contributed to the Malaysia economic growth. Additionally, the arrival of international labour in Malaysia is to help meet the shortage of labour of the various economic sectors of the country. The numbers of international labours have increased from year to year whereby assisting companies to save costs by employed labors in lower scale salary (Mohamed et al., 2012). However, their arrival if not controlled, will decrease the local population's employment opportunities and creating negative impacts of the migration into the country (Hassan, 2009).

A study by Bachtiar et al. (2015) suggested that the contribution of professional international labours to outputs' growth is relatively small compared to middle and heavy industries that intensively utilize physical capital even though the demand for it is still beneficial. In contrast, the demand for skilled and technical-supervisor international labours for the food, beverage and tobacco industries are still needed due to technological development in the production process.

In spite of the large number of international migrant labours and the problems associated with their presence, the Malaysian government is yet to come up with a comprehensive policy on the issue. Mohamed et al. (2012) also emphasized that the issue of international labours has received increase media and national attention. Additionally, the Government has been collecting labour force data for an extended period of time. However, the data on international migrant labours who are working in the tourism and hospitality industry is not properly recorded. Furthermore, previous studies did not focus on developing the international migrant labours profile. It is also noted that there has been limited research on the nature and consequences of employment of international labours in Malaysia.

There has been a report on profiling the international migrant labours who are working in Malaysia by Del Carpio et al. (2013). However, the report presents a profile of the labours in various sectors such as constructions, transportation, teaching professionals and medical officers. Even though the report has presented related data on international migrant labours in the tourism and hospitality industry, the numbers are in general context within the scope of service sectors. Hence, the purpose of this study is mainly to profile the international migrant labours who are legally working in the tourism and hospitality industry specifically in Langkawi by their socio-demographic characteristics and motivational factors.

Langkawi has been chosen based on the fact that it is the world known tourist destination. It is important to study and understand the international migrant labours characteristics and motivational factors through answering few questions for instance:

- What are the socio-demographic characteristics of the international migrant labours who are working in the tourism and hospitality industry in Langkawi?

- What factors motivate them to work in the tourism and hospitality industry?

- What factors motivate them to work in the particular sector in the tourism and hospitality industry?

- What factors motivate them to choose Langkawi?

The profiling of the international migrant labours by their socio-demographic characteristics and motivational factors would eventually assist the Workforce Department particularly in designing and preparing new policy for the Work Act 1955 and the Immigration Act 1959.

\section{Literature review}

Tourism can bring about migration within the labour force, through the creation of employment opportunities. In fact, the migration of labours to the tourism destination is common to both developed and developing countries. However, the developed countries of tourist destinations may be in a stronger position to absorb new migrants due to their more diversified and stable economic base. On the level of the individual, migration can be seen as an investment in human resources and is often motivated by low levels of income in rural areas. Permanent migrants are those who make a permanent move to the new area for tourism employment, whereas circular migrants return to 
their home base periodically or after a certain time. Permanent migrants add considerably to urbanization pressures while, in general, circular migrants, although contributing greatly to and benefitting from tourism employment, do not.

In the tourism industry itself, an excess of $11,194,418$ people are employed worldwide and presented approximately 5 per cent of the world's total travel and tourism workforce. Monk and Alexander (1986) in their study found that migrants to Margarita Island, Venezuela, are the main beneficiaries of tourism-generated employment, since many of the newly-created jobs are either inaccessible to the poorer segments of the local population or unattractive to the better off segments.

Further supporting this claim, Lee-Ross and Pryce (2010) highlighted that one of the complexities of tourism employment is that establishments that may have a mainstay of domestic and international tourists will also be used by locals, especially during the off season. In fact, the presence in large numbers of migrant workers in such hospitality organizations is of consequence for tourism academics as it carries implications for both destination image and the tourist experience of the destination.

Many migrants are found to share a number of characteristics: they tended to be young, predominantly male, had more than primary level education, and came from wide socioeconomic strata. Earliest study by Todaro (1976) emphasized seven research priorities which would help to explain migration and its impact on the development of developing countries namely:

- Migrant perceptions, expectations and experiences and how these are formulated.

- Characteristics of non-migrants, potential migrants and return migrants.

- Importance of employment probabilities and expected income.

- Wage and employment probability elasticities, and urban unemployment.

- Short- and long-term social and economic impact of migration on source and destination areas.

- The relationship between education and migration.

- Migration, income distribution, and population growth.

Although many studies suggest positive outcomes from employing foreign labours, some negative consequences for the industry have also been identified. Choi et al. (2000) and Williams and Hall (2000) argued that this ongoing relationship between migration, migrant labour and tourism employment continues partly because a mobile international workforce offers a solution to labour shortages where the local workforce is not willing to engage in low pay, low status and seasonal employment.

Furthermore, the employment of international labours in tourism and related service sectors presents a series of opportunities alongside challenges for migrants, employers and host communities. Few studies also highlighted that migration has been argued as a source of innovation where if it is properly managed, the organizations can benefit from cultural diversity (Devine et al., 2007; Williams, 2007).

Additionally, migrants are also found to become a source of community tension, particularly if they are perceived to be a burden on community resources, to represent competition for jobs or if they do not integrate into the host society and thus seem to challenge social norms (Rogers et al., 2009). Migrants' lack of integration may be intensified by tourism employment, for example when employment patterns restrict social mobility or when organizations reinforce the formation of ethnic enclaves and social closure. It is also argued that tourism employment may offer opportunities for greater social inclusion and help to facilitate migrant adaptation to the host culture.

\section{Methodology}

The study was an exploratory study to profile the international migrant labours. Hence, it involved a quantitative method where questionnaire had been developed to gain major information for the purpose of profiling them by their socio-demographic characteristics and investigating their motivational factors.

\subsection{Data collection}

The primary data of the study was acquired through distributing questionnaire to target respondents. It is considered as main means to collect primary data and enable researcher to reach large number of respondents at lowest cost with high flexibility. To achieve this objective, Langkawi was chosen to represent the scope of the study. This is due to the fact that Langkawi is known as the world tourist destination, thus it consists of many tourism and hospitality sectors. The service sectors categorized under the tourism and hospitality within the area of Pantai Cenang, Langkawi were involved as unit of analysis of the study. This included of 3, 4 and 5 star hotels, fast food service restaurants, visitor attractions sites, transportation and international cuisine restaurants. Pantai Cenang was selected as it represents major tourism spots and activities in Langkawi.

The human resource managers or related officers at the sectors were personally approached by the research assistant asking their participation in the study. Upon their agreement to participate in the study, the survey questionnaires were handed in and they were asked to distribute the questionnaires to their international workers. The completed questionnaires were collected by the research assistant within 2 weeks. On the other hands, the secondary data in the study was assessed and analysed using all other sources such as literature 
search and reports from various parties. Literature search also covered relevant online journal articles through online databases and also the reports from newspapers and published statistics.

\subsection{Population and sample}

The target population of the study was the international migrant labours who are legally working in the tourism and hospitality industry in Langkawi. Since there is no exact number of the international migrant labours who are working in the service sector specifically in Langkawi, the number of population was determined according to the general number of international migrant labours in Malaysia as stated by the Department of Statistic of Malaysia in 2012. There was 291,997.44 international migrant labours working in the service sector and using a table of sample size provided by Krejcie and Morgan (1970), 384 respondents was selected to represent the sample. The study applied a purposive sampling technique where only the international migrant labours legally working in the tourism and hospitality industry was selected. The selected technique eventually enabled researches to obtain questionnaires quickly and economically (Sekaran and Bougie, 2010). To obtain a balance number of questionnaires distributed to the sectors, the sample size was determined as 400 respondents and 20 sectors were selected for the study. Hence, each sector was provided with 20 questionnaires to be filled up by the respondents. Since there is no exact number of tourism and hospitality sectors in Pantai Cenang, the sample were randomly approached by the researcher.

\subsection{Instrument design}

Since the purpose of the study was to develop a profile of international migrant labours who are working in the tourism and hospitality sector, a selfadministered survey questionnaire was used as research instrument. This type of questionnaire was chosen because of its ease of use and it provides the most possible alternative for measuring unobservable constructs such as attitudes, values and personalities. Further, according to Sekaran and Bougie (2010), survey questionnaire is an efficient data collection mechanism to ensure relevancy and consistency of information gathered as the responses are objective, standardised and comparable. Additionally, the questionnaire was designed and presented in simple and unbiased wordings. The purpose was to make sure that the respondents can easily understand the questions and provide answer based on their own perception.

The questionnaire was divided into two sections namely Section A and Section B. Section A consisted of respondent's socio-demographic profiles such as gender, age, marital status, country of origin, educational level, qualification, skills level, proficiency in English, job in sector, job position, number of years working in the sector and income per month. Section B consisted of three major questions asking the respondents on the factors motivating them; (1) to work in the tourism and hospitality industry, (2) to work in the particular sector in the tourism and hospitality industry and (3) to choose Langkawi.

\subsection{Data analysis}

The study used the Statistical Program for Social Science (SPSS) with descriptive and inferential analysis to identify patterns and general trends in the dataset of this study. Descriptive analysis refers to the transformation of raw data into a form that make them easier to understand and interpret. Hence, descriptive analyses such as frequency counts, percentages and cumulative percentages were employed in this study to develop the profiles of international migrant labours as in Section A. In addition they were also used to describe items in Section B of the questionnaire.

\section{Findings}

\subsection{Socio-demographic characteristics}

Table 1 depicts the profile of international migrant labours by the socio-demographic characteristics. A total of 258 useable questionnaires out of 400 were obtained, representing $64.5 \%$ response rate. It is indicated that $70.5 \%$ respondents are male and the remaining $29.5 \%$ are female. As for the age distribution, the survey showed that $2.7 \%$ are below 18 years old, $69.4 \%$ are between 18 to 30 years old, $27.1 \%$ are between 31 to 50 years old and the remaining of $0.8 \%$ are above 50 years old. The survey also asked the respondents their marital status and the findings highlighted that most respondents are single (51.9\%). Meanwhile 40.3\% are married, $4.3 \%$ are divorced and another 3.5\% provided as other category.

The respondents were further asked to state their country of origin. The findings of the survey indicated the highest percentage is from Indonesia $(21.3 \%)$. The findings then revealed that $17.8 \%$ respondents are from India, followed by $15.9 \%$ respondents from Bangladesh, $12.4 \%$ from Philippines, $8.5 \%$ from Thailand, 2.7\% from Pakistan and $0.4 \%$ from Vietnam. However, the findings also indicated that $20.9 \%$ respondents are from other countries such as Nepal, United Kingdom and few are from Maldives. The respondents were also asked to indicate their educational level and the findings emphasized that majority are educated from secondary school (41.1\%), followed by high school (38.4\%), college (13.6\%) and university (7.0\%).

Additionally, majority of the respondents have possessed a certificate (50.8\%). In fact, most of them have also possessed diploma/higher diploma $(43.0 \%)$ and followed by undergraduate degree $(5.0 \%)$ and postgraduate degree $(1.2 \%)$. As for the skills level, the findings indicated that $66.3 \%$ of the 
respondents are semi-skilled while the rest is unskilled (33.7\%).

Table 1: International migrant labours socio-demographic characteristics

\begin{tabular}{|c|c|c|c|c|}
\hline Items & Frequency & Percent & Valid Percent & Cumulative Percent \\
\hline \multicolumn{5}{|l|}{ Gender } \\
\hline Male & 182 & 70.5 & 70.5 & 70.5 \\
\hline Female & 76 & 29.5 & 29.5 & 100.0 \\
\hline \multicolumn{5}{|l|}{ Age } \\
\hline Below 18 years old & 7 & 2.7 & 2.7 & 2.7 \\
\hline $18-30$ years old & 179 & 69.4 & 69.4 & 72.1 \\
\hline $31-50$ years old & 70 & 27.1 & 27.1 & 99.2 \\
\hline \multirow{2}{*}{\multicolumn{5}{|c|}{ Marital status }} \\
\hline & & & & \\
\hline Single & 134 & 51.9 & 51.9 & 51.9 \\
\hline Married & 104 & 40.3 & 40.3 & 92.2 \\
\hline Divorced & 11 & 4.3 & 4.3 & 96.5 \\
\hline Others & 9 & 3.5 & 3.5 & 100.0 \\
\hline \multicolumn{5}{|l|}{ Country of origin } \\
\hline Bangladesh & 41 & 15.9 & 15.9 & 15.9 \\
\hline Philippines & 32 & 12.4 & 12.4 & 28.3 \\
\hline Indonesia & 55 & 21.3 & 21.3 & 49.6 \\
\hline India & 46 & 17.8 & 17.8 & 67.4 \\
\hline Pakistan & 7 & 2.7 & 2.7 & 70.2 \\
\hline Thailand & 22 & 8.5 & 8.5 & 78.7 \\
\hline Vietnam & 1 & .4 & .4 & 79.1 \\
\hline Others & 54 & 20.9 & 20.9 & 100.0 \\
\hline \multicolumn{5}{|l|}{ Educational level } \\
\hline Secondary school & 106 & 41.1 & 41.1 & 41.1 \\
\hline High school & 99 & 38.4 & 38.4 & 79.5 \\
\hline College & 35 & 13.6 & 13.6 & 93.0 \\
\hline University & 18 & 7.0 & 7.0 & 100.0 \\
\hline \multicolumn{5}{|l|}{ Qualification } \\
\hline Certificate & 131 & 50.8 & 50.8 & 50.8 \\
\hline Diploma/higher diploma & 111 & 43.0 & 43.0 & 93.8 \\
\hline Undergraduate degree & 13 & 5.0 & 5.0 & 98.8 \\
\hline Postgraduate degree & 3 & 1.2 & 1.2 & 100.0 \\
\hline \multicolumn{5}{|l|}{ Skills level } \\
\hline Unskilled & 87 & 33.7 & 33.7 & 33.7 \\
\hline Semi-skilled & 171 & 66.3 & 66.3 & 100.0 \\
\hline \multicolumn{5}{|l|}{ Proficiency in English } \\
\hline Very little & 44 & 17.1 & 17.1 & 17.1 \\
\hline Little & 63 & 24.4 & 24.4 & 41.5 \\
\hline Good & 93 & 36.0 & 36.0 & 77.5 \\
\hline \multirow{2}{*}{\multicolumn{5}{|c|}{ Job in sector }} \\
\hline & & & & \\
\hline Accommodation & 106 & 41.1 & 41.1 & 41.1 \\
\hline Transportation & 3 & 1.2 & 1.2 & 42.2 \\
\hline Food and beverages & 84 & 32.6 & 32.6 & 74.8 \\
\hline Visitor attractions & 27 & 10.5 & 10.5 & 85.3 \\
\hline Others & 38 & 14.7 & 14.7 & 100.0 \\
\hline \multicolumn{5}{|l|}{ Job position } \\
\hline Administration & 16 & 6.2 & 6.2 & 6.2 \\
\hline Customer service & 195 & 75.6 & 75.6 & 81.8 \\
\hline Security service & 15 & 5.8 & 5.8 & 87.6 \\
\hline Others & 32 & 12.4 & 12.4 & 100.0 \\
\hline \multirow{2}{*}{\multicolumn{5}{|c|}{$\begin{array}{l}\text { Number of years } \\
\text { working in the sector }\end{array}$}} \\
\hline & 63 & 24.4 & 24.4 & 24.4 \\
\hline Less than 1 year & 159 & 61.6 & 61.6 & 86.0 \\
\hline $1-5$ years & 31 & 12.0 & 12.0 & 98.1 \\
\hline $6-10$ years & 5 & 1.9 & 1.9 & 100.0 \\
\hline \multicolumn{5}{|l|}{ Income per month } \\
\hline Less than RM1,000 & 40 & 15.5 & 15.5 & 15.5 \\
\hline RM1,000 - RM4,999 & 215 & 83.3 & 83.3 & 98.8 \\
\hline RM5,000 - RM9,999 & 2 & 0.8 & 0.8 & 99.6 \\
\hline More than RM10,000 & 1 & 0.4 & 0.4 & 100.0 \\
\hline
\end{tabular}

Majority of them also stated that they can speak good English (36.0\%) and very good English (22.5\%). The remaining stated as can speak little English (24.4\%) and very little English (17.1\%).

Further, the respondents were asked to provide their working sector. It was noted that most of them are working in the accommodation sector (41.1\%), followed by the food and beverages sector (32.6\%), other tourism and hospitality related sectors $(14.7 \%)$, the visitor attractions sector $(10.5 \%)$ and the transportation sector $(1.2 \%)$.

The survey question further asked the respondents to indicate their position in the sector. Majority of them involved in the customer service (75.6\%), followed by other positions (12.4\%), administration (6.2\%) and only few in the security 
service $(5.8 \%)$. As for the question on the number of years working in the sector, the findings highlighted that majority of the respondents have been working for 1 - 5 years $(61.6 \%)$. This is followed by $24.4 \%$ of them have been working less than 1 year, $12.0 \%$ have been working for $6-10$ years and the remaining $1.9 \%$ have been working for more than 10 years.

Additionally, $83.3 \%$ of the respondents received an income of RM1,000 - RM4,999 per month, followed by $15.5 \%$ received an income less than RM1,000 and the remaining received of RM5,000 and more than RM10,000 income per month.

\subsection{Factors motivating them to work in the tourism and hospitality industry}

The respondents were also asked to indicate eight factors that motivate them to work in the tourism and hospitality industry. The factors were categorized as high wages, easy to get job, family concerns, gain new experience, following friends, job promotion and other factors. Table 2 highlighted the findings of this survey. Majority of the respondents agreed that the main factor for them to work in the tourism and hospitality industry is to gain new experience' (52.3\%).

Most of them also agreed that they tend to 'follow their friends' (41.1\%) and also because of the 'high wages' (37.2\%). Mostly, the respondents agreed that the factor motivates them to work in the industry is because they, 'love meeting with people' (28.3\%), 'easy to get job' (22.1\%), 'job promotion' (7.8\%) and 'family concerns' (7.4\%). Only few respondents stated other factors for choosing the industry (5.4\%).

Table 2: Factors motivating them to work in the tourism

\begin{tabular}{ccc}
\multicolumn{3}{c}{ and hospitality industry } \\
\hline Items & Frequency & Percent \\
\hline To gain new experience & 135 & 52.3 \\
Following friends & 106 & 41.1 \\
High wages & 96 & 37.2 \\
Love meeting with people & 73 & 28.3 \\
Easy to get job & 57 & 22.1 \\
Job promotion & 20 & 7.8 \\
Family concerns & 19 & 7.4 \\
Other reasons & 14 & 5.4 \\
\hline
\end{tabular}

\subsection{Factors motivating them to work in the particular sector of tourism and hospitality}

Finally, the respondents were also asked to indicate six factors that motivate them to work in the particular sector of tourism and hospitality industry namely, high wages, an opportunity to be promoted, easy to get job, attractive incentives, no strict policies and other factors. Table 3 depicts the findings of the survey which emphasised that majority of them agreed that the sector was chosen because it is 'easy to get the job' (53.5\%). Further, most of the respondents also agreed that the sector provides 'high wages' (38.0\%), 'attractive incentives' (29.1\%), involve of 'no strict policies' (27.9\%) and have more 'opportunity to be promoted' (21.3\%). Only few of the respondents agreed with other related factors for choosing the particular sector (5.0\%).

Table 3: Factors motivating them to work in the tourism

\begin{tabular}{ccc}
\multicolumn{3}{c}{ and hospitality sector } \\
\hline Items & Frequency & Percent \\
\hline Easy to get job & 138 & 53.5 \\
High wages & 98 & 38.0 \\
Attractive incentives & 75 & 29.1 \\
No strict policies & 72 & 27.9 \\
Opportunity to be promoted & 55 & 21.3 \\
Other reasons & 13 & 5.0 \\
\hline
\end{tabular}

\subsection{Factors motivating them to choose Langkawi}

There were seven factors provided to the respondents regarding Langkawi as the chosen destination. The factors were identified as Table 4 presents the profile of the motivational factors. Majority of the respondents emphasized that the main factor for choosing Langkawi is because of the 'beautiful island' (50.8\%). Most of them also noted the reason for being as 'easy place to get around' $(32.9 \%)$ and they considered Langkawi as a 'peaceful place' $(32.2 \%)$. Further, the respondents also found that one of the factors is because of 'friendly people in Langkawi' (31.4\%). The findings also indicated that on average, the respondents also agreed with few more factors such as 'company concerns' (24.0\%), 'family concerns' (12.0\%) and other reasons $(7.4 \%)$.

Table 4: Factors motivating them to choose Langkawi

\begin{tabular}{ccc}
\hline Items & Frequency & Percent \\
\hline Beautiful island & 131 & 50.8 \\
Easy to get around & 85 & 32.9 \\
Peaceful place & 83 & 32.2 \\
Friendly people & 81 & 31.4 \\
Company concerns & 62 & 24.0 \\
Family concerns & 31 & 12.0 \\
Other reasons & 19 & 7.4 \\
\hline
\end{tabular}

\section{Conclusion}

Four objectives have derived to achieve the purpose of the study; investigating the sociodemographic characteristics of the international migrant labours, investigating the factors that motivate them to work in the tourism and hospitality industry, investigating the factors that motivate them to work in the particular sector within the industry and also investigating the factors that motivate them to choose Langkawi.

The profile of international migrant labours indicates that majority of the labours who are working in Langkawi are male and only few are female with the age between 18 - 30 years old. Both male and female labours are mostly still single. Additionally, the profile shows that most of the male migrant labours were secondary school leavers whilst the female migrant labours were high school leavers. The profile is significant as reported in the study conducted by Del Carpio et al. (2013). 
Further, the findings also indicate that most of the international migrant labours in Langkawi migrate from Indonesia. They are considered as semi-skilled labours and can communicate good English. This profile is also significant to the study conducted by Bachtiar et al. (2015). The profile also highlights that majority of the international migrant labours in Langkawi are working in the accommodation sector between 1 - 5 years with income of RM1,000 - RM4,999 per month.

It can be concluded from the profiles that the Indonesian migrate to work in the tourism and hospitality industry in Langkawi because they wanted to gain new experience. They also noted that the tourism and hospitality industry provide them with high wages compared to other industries. More, the international migrant labours have chosen to work in the accommodation sector due to the fact that they considered the sector as easy to get the job and in addition, they also believed the sector can provide high wages to the employees. Interestingly, the profile supports what has been concluded by Bachtiar et al. (2015).

This study only focuses on profiling the international migrant labours who are working in the tourism and hospitality industry by their sociodemographic characteristics. Additionally it also investigates the factors motivating the international migrant labours to work in the industry. In this case, Langkawi has been chosen based on the fact that it is a world known tourist destination which eventually represents a wide scope of tourism and hospitality industry. It is therefore suggested that more studies to be conducted to enhance the knowledge and practical side of recruiting international migrant labours in the industry.

For instance, a further study to investigate the relationship between the socio-demographic characteristics and factors for choosing the industry should be conducted and would assist the sector in planning more strategic approach to recruit the international migrant labours. Another study would be on comparing the differences in factors influencing them to work in the industry according to their country of origin. This study would also provide the particular sector towards better understanding on the factors motivate the international migrant labours to choose the industry. The profiles significantly would contribute to the industry in terms of recruiting the international migrant labours to fill-in the job according to their socio-demographic characteristics and motivational factors.

\section{Acknowledgement}

This study is sponsored by the Malaysian Ministry of Higher Education under the Fundamental Research Grant Scheme (FRGS) S/O code 13029.

\section{References}

Ajis MN, Keling MF, Othman Z, and Shuib MS (2014). The dilemma of managing foreign workers in Malaysia: opportunities and challenges. Global Journal of Human Social-Science: Political Science, 14(4):43-53.

Bachtiar N, Fahmy R, and Ismail R (2015). The demand for foreign workers in the manufacturing sector in Malaysia. Jurnal Ekonomi Malaysia, 49(92): 135-147.

Choi JG, Woods RH, and Murrmann SK (2000). International labor markets and the migration of labor forces as an alternative solution for labor shortages in the hospitality industry. International Journal of Contemporary Hospitality Management, 12(1): 61-67.

Del Carpio X, Karupiah R, Marouani M, Ozden C, Testaverde M, and Wagner M (2013). Immigration in Malaysia: Assessment of its Economic Effects, and a Review of the Policy and System. World Bank, Washington DC. Vancouver, Canada.

Devine F, Baum T, Hearns N, and Devine A (2007). Cultural diversity in hospitality work: the Northern Ireland experience. International Journal of Human resource Management, 18(2): 333-349.

Hassan CH (2009). Buruh asing di Malaysia: Trend, kaedah, kesan, masalah dan cara mengatasinya [Foreign labour in Malaysia: trends, methods, impacts, problems and strategies to solve the problems]. Journal of Southeast Asian Studies, 14(1): 119-132.

IOM (2010). International Organization for Migration, Labour migration from Indonesia: An overview of Indonesia migration to selected destinations in Asia and the Middle-East. International Organization for Migration, Jakarta, Indonesia. Available online at: http://www.iom.int/jahia/webdav/ shared/shared/mainsite/published_docs/Final-LM-ReportEnglish.pdf

Krejcie RV and Morgan DW (1970). Determining sample size for research activities. Educational and Psychological Measurement, 30(3): 607-610.

Lee-Ross D and Pryce J (2010). Human resources and tourism: Skills, culture and industry. Channel View Publications, Bristol, UK.

Mohamed RKMH, Ramendran C, and Yacob P (2012). The impact of employment of foreign workers: Local employability and trade union roles in Malaysia. International Journal of Academic Research in Business and Social Sciences, 2(10): 530-541.

Monk J and Alexander C (1986). Free port fallout: gender, employment, and migration on Margarita Island. Annals of Tourism Research, 13(3): 393-413.

Rogers A, Anderson B, and Clark N (2009). Recession, vulnerable workers and immigration. Center on Migration, Policy and Society (COMPAS). Available online at: https://www.compas. ox.ac.uk/media/PR-2009-Recession_Vulnerable_Workers.pdf

Sekaran U and Bougie R (2010). Research methods. For business: a skill building approach. $5^{\text {th }}$ Edition, John Wiley \& Sons, West Sussex, UK.

Todaro MP (1976). Internal migration in developing countries. International Labour Office, Geneva, Switzerland.

Williams A and Hall CM (2000). Tourism and migration: new relationships between production and consumption. Tourism Geographies, 2(1), 5-27.

Williams AM (2007). International labour migration and tacit knowledge transactions: a multi-level perspective. Global Networks, 7(1): 29-50. 